Syntax Literate: Jurnal Ilmiah Indonesia p-ISSN: 2541-0849

e-ISSN: 2548-1398

Vol. 5, No. 7, Juli 2020

\title{
PENGARUH MODEL GUIDED DISCOVERY LEARNING BERBASIS MEDIA AUDIOVISUAL TERHADAP HASIL BELAJAR IPA
}

\section{Anggi Pramowardhani}

Fakultas Keguruan dan Ilmu Pendidikan Universitas Islam Al Ihya Kuningan

Email: anggipramowardhani@gmail.com

\begin{abstract}
This study aims to determine the influence of guided discovery learning model of audiovisual media on the learning outcomes sains on the concept of light and its properties in SDN 1 Sukamulya. This research is an experimental research. The population in this study are the students of grade $V$ of SDN 1 Sukamulya. The sampling technique used is the total sampling in which the authors set the population to be a research sample. So the research sample used is the students of grade V.A which amounted to 30 students as experimental group and students of grade V.B which amounted to 30 students. The data collection technique used is multiple choice test. Data analysis technique in this research is normality test, homogeneity test and hypothesis test ( $t$ test) used for the influence of guided discovery learning model of audiovisual media toward class $V$ student learning outcomes on the concept of light and its properties in SDN 1 Sukamulya. Based on the calculation of hypothesis test by using $t$ test, $t$ data obtained hit $(5,70)>t$ daf $(1,67)$, then Hi accepted means that there is influence of guided discovery learning model of audiovisual media on the learning outcomes sains on the concept of light and its properties in SDN 1 Sukamulya. The conclusion of this research is that there is influence of guided discovery learning model of audiovisual media on the learning outcomes sains on the concept of light and its properties in SDN 1 Sukamulya.
\end{abstract}

Keywords: Guided Discovery Learning Model; Audiovisual Media; Student Learning Outcomes.

\footnotetext{
Abstrak

Penelitian ini bertujuan untuk mengetahui pengaruh model guided discovery learning berbasis media audiovisual terhadap hasil belajar IPA pada konsep cahaya dan sifat-sifatnya di Kelas V SD Negeri 1 Sukamulya. Penelitian ini merupakan penelitian eksperimen. Populasi pada penelitian ini adalah siswa kelas V SD Negeri 1 Sukamulya. Teknik pengambilan sampel yang digunakan adalah total sampling dimana penulis menetapkan populasi menjadi sampel penelitian. Jadi sampel penelitian yang digunakan adalah siswa kelas V.A SD Negeri 1 Sukamulya yang berjumlah 30 siswa sebagai kelompok eksperimen dan siswa kelas V.B SD Negeri 1 Sukamulya yang berjumlah 30 siswa. Teknik pengumpulan data yang digunakan adalah tes pilihan ganda. Teknik analisis data dalam penelitian ini adalah uji normalitas, uji homogenitas dan uji hipotesis (uji t) yang digunakan untuk pengaruh model guided discovery learning berbasis media audiovisual terhadap hasil belajar
} 
IPA pada konsep cahaya dan sifat-sifatnya di Kelas V SD Negeri 1 Sukamulya. Berdasarkan perhitungan uji hipotesis dengan menggunakan uji $t$ diperoleh data $t$ hit $(5,70)>t$ daf $(1,67)$, maka Hi diterima artinya bahwa terdapat pengaruh model guided discovery learning berbasis media audiovisual terhadap hasil belajar IPA pada konsep cahaya dan sifat-sifatnya di Kelas V SD Negeri 1 Sukamulya. Kesimpulan dalam penelitian ini adalah terdapat pengaruh model guided discovery learning berbasis media audiovisual terhadap hasil belajar IPA pada konsep cahaya dan sifat-sifatnya di Kelas V SD Negeri 1 Sukamulya.

Kata kunci: Model Guided Discovery Learning; Media Audiovisual; Hasil Belajar Siswa.

\section{Pendahuluan}

Keberhasilan pembelajaran dapat dilihat dari kualitas yang diperoleh oleh siswa. Jika para siswa mampu menguasai apa yang mereka pelajari sesuai dengan tujuan pembelajaran yang diharapkan, maka dapat dipastikan keberhasilan pembelajaran telah tercapai. Peran serta guru sangat penting untuk menciptakan suasana belajar yang kondusif, sehingga dapat meningkatkan pemahaman materi yang dipelajari termasuk juga hasil belajar siswa yang memuaskan.

Sanjaya menjelaskan bahwa Hasil belajar siswa merupakan hasil kegiatan belajar, yaitu sejauhmana siswa menguasai bahan pelajaran yang diajarkan, yang diikuti oleh munculnya perasaan puas bahwa siswa telah melakukan sesuatu dengan baik (Sanjaya, 2019). Hal ini berarti prestasi belajar hanya bisa diketahui jika telah dilakukan penilaian terhadap hasil belajar siswa.

Berdasarkan hasil studi pendahuluan yang peneliti laksanakan di SD Negeri 1 Sukamulya Kabupaten Kuningan pada mata pelajaran IPA kelas V hasil belajar siswa masih rendah. Hal ini terlihat dari nilai ulangan harian dalam mata pelajaran IPA dimana sebagian besar siswa kelas V di SD Negeri 1 Sukamulya Kabupaten Kuningan yaitu sebesar 71\% memperoleh nilai IPA di bawah Kriteria Ketuntasan Minimal (KKM) yang telah ditetapkan yaitu 70 (Wawancara dengan Guru Kelas V SDN 1 Sukamulya)

Menurut Dimyanti“Model guided discovery learning merupakan suatu model pembelajaran yang terpusat pada siswa, dimana siswa didorong untuk berpikir sendiri dalam mencari dan menemukan suatu pengetahuan, dimana guru hanya bertindak sebagai pembimbing, pemberi petunjuk dan fasilitator (Dimyanti, 2014). Model guided discovery learning dapat melatih siswa dalam mencari dan mengumpulkan data di lapangan, siswa terlibat secara aktif dalam penemuan atau memperoleh pengetahuan dan informasi serta meningkatkan hasil belajar siswa.

Widdiharto (2012 : 8) mengemukakan bahwa model guided discovery learning berbasis media audiovisual dimulai kelompok belajar mendiskusikan masalah untuk dipecahkn melalui pengumpulan data, kelompok belajar merumuskan dan menetapkan jawaban sementara, siswa melakukan penemuan dengan pengumpulan dan pengolahan data, siswa dalam kelompok belajar mencatat, menganalisis penemuan dan pengamatan, kelompok belajar menyelesaikan LKS dengan memanfaatkan berbagai sumber belajar, 
kelompok belajar mendiskusikan konsep berdasarkan hasil penemuan, dan kelompok belajar membuat kesimpulan jawaban hasil penemuan sehingga meningkatkan hasil belajar siswa.

Sebagaimana dikemukakan oleh Hadiningsih kelebihan model guided discovery learning adalah siswa belajar bagaimana belajar (learn to how learn), belajar menghargai diri sendiri, memotivasi diri dan lebih mudah untuk mentransfer, memperkecil atau menghindari menghafal dan siswa bertanggung jawab atas pembelajarannya sendiri, siswa lebih memahami sains dan teknologi, dan siswa dapat memecahkan masalah, karena mereka benar-benar diberi kesempatan berperan serta didalam kegiatan sains sesuai dengan perkembangan intelektual mereka dengan bimbingan guru (Hadiningsih, 2016).

Penerapan model guided discovery learning dapat dikolaborasikan dengan penggunaan media audiovisual. Munadi menyatakan bahwa "Media audiovisual adalah alat bantu yang berupa gambar dan suara dalam menerima suatu pesan, sehingga siswa dapat memperoleh ilmu dan pengalaman yang bermanfaat untuk meraih tujuan yang ingin dicapai" (Munadi, 2015). Penggunaan media audiovisual yang tepat dalam kegiatan pembelajaran dapat meningkatkan interaksi dan komunikasi yang baik diantara guru dengan siswa, menumbuhkan minat dan motivasi belajar, meningkatkan efektivitas penyampaian materi pembelajaran dan meningkatkan motivasi belajar siswa.

Kusumah yang mengemukakan bahwa kelebihan media audiovisual adalah memberikan dasar-dasar konkrit untuk berpikir, membuat pelajaran lebih menarik, memungkinkan hasil belajar lebih tahan, memberikan pengalaman-pengalaman yang nyata, mengembangkan keteraturan dan kontinuitas berpikir, dan dapat memberikan pengalaman-pengalaman yang tidak diperoleh lewat cara lain dan membuat kegiatan belajar lebih mendalam efisien dan beraneka ragam (Kusumah, 2015).

Hasil penelitian Wati membuktikan bahwa terdapat model discovery learning terhadap pemahaman konsep pada siswa kelas VII SMP Negeri 4 Cirebon. Berdasarkan hasil pengujian statistik $\mathrm{t}$ hit $(10,283)>\mathrm{t}$ daf $(1,67)$, maka terima Hi artinya terdapat pengaruh model discovery learning terhadap pemahaman konsep pada siswa kelas VII SMP Negeri 4 Cirebon (Wati, 2012).

Hasil penelitian Iskandar (2016) menunjukkan bahwa terdapat pengaruh yang signifikan penggunaan media audiovisual terhadap motivasi belajar dan hasil belajar kelas v pada mata pelajaran IPS di SD Negeri 2 Patala Kecamatan Cilebak Kabupaten Kuningan Tahun Ajaran 2015/2016.

Penelitian ini bertujuan untuk mengetahui implementasi model guided discovery learning berbasis media audiovisual terhadap peningkatan hasil belajar IPA.

Bertitik tolak dari pendapat di atas, penulis memberikan hipotesis adalah "Terdapat pengaruh model guided discovery learning berbasis media audiovisual terhadap hasil belajar siswa IPA". 


\section{Metodologi Penelitian}

Penelitian dilaksanakan di SD Negeri 1 Sukamulya yang beralamat di Jln. Raya Sukamulya Kelurahan Sukamulya Kecamatan Cigugur Kabupaten Kuningan 45552. Metode yang digunakan dalam penelitian ini adalah metode eksperimen. Adapun dalam eksperimen yang digunakan dalam penelitian ini adalah "nonequivalent Group pretestposttest design" atau control group tidak menerima perlakuan. Menurut Schumacher desain ini dapat digambarkan sebagai berikut :

\section{Nonequivalent Group pretest-posttest design}

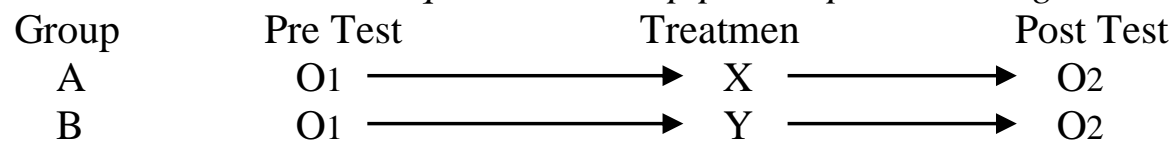

Keterangan :

A $=$ Kelompok eksperimen

$\mathrm{B} \quad=$ Kelompok kontrol

O1 = Tes awal diberikan pada kelompok eksperimen dan kelompok kontrol

$\mathrm{O} 2=$ Tes Akhir diberikan pada kelompok eksperimen dan kelompok kontrol

$\mathrm{X}=$ Perlakuan model guided discovery learning berbasis media audiovisual

$\mathrm{Y}=$ Perlakuan model konvensional.

Populasi pada penelitian ini adalah siswa kelas V.A SD Negeri 1 Sukamulya Kabupaten Kuningan yang berjumlah 30 siswa sebagai kelompok eksperimen dan siswa kelas V.B SD Negeri 1 Sukamulya Kabupaten Kuningan yang berjumlah 30 siswa. Teknik pengambilan sampel yang digunakan dalam penelitian ini adalah total sampling, dimana penulis menetapkan populasi sebagai sampel penelitian sehingga sampel yang didapat adalah siswa kelas V.A SD Negeri 1 Sukamulya Kabupaten Kuningan yang berjumlah 30 siswa sebagai kelompok eksperimen dan siswa kelas V.B SD Negeri 1 Sukamulya Kabupaten Kuningan yang berjumlah 30 siswa.

Dalam penelitian ini tes yang dibuat adalah tes pilihan ganda. Tes ini dilakukan sebanyak 2 kali.

1. Pre Test

Merupakan uji awal sebelum dilakukan eksperimen pada sampel penelitian dan menjadi langkah awal dalam penyamanan kondisi kelompok eksperimen. Tes awal (pretes) dilakukan untuk mengetahui rata-rata hasil belajar IPA. Tes awal kelas eksperimen dilakukan sebelum menggunakan model guided discovery learning berbasis media audiovisual.

2. Post Test

Merupakan uji akhir eksperimen, yaitu setelah dilaksanakannya eksperimen. Tes akhir (posttes) dilakukan untuk mengetahui perkembangan kemampuan siswa setelah menggunakan model guided discovery learning berbasis media audiovisual pada kelas eksperimen.

Teknik Analisis Data

1. Prasyarat Statistik 
Adapun langkah-langkah yang dilakukan dalam pengolahan data tersebut adalah sebagai berikut :

a. Melakukan Uji Normalitas data

1) Menentukan rata-rata dan standar deviasi

$$
\bar{X}=\sum \frac{f x}{f} \quad \quad \mathrm{Sd}=\sqrt{\frac{n_{1}\left(\sum(f x)^{2}\right)-\left(\sum f x\right)^{2}}{n(n-1)}}
$$

Keterangan $: X=$ rata-rata

Sd $=$ Standar Deviasi

2) Menentukan rentang kelas, banyak kelas dan panjang kelas dengan menggunakan rumus :

$\mathrm{r}=$ data terbesar - data terkecil

$\mathrm{k}=1+3,3 \log \mathrm{n}$

$\mathrm{p}=\mathrm{r} / \mathrm{k}$

Keterangan : $\quad \mathrm{r}=$ Rentang

$\mathrm{k}=$ Banyaknya kelas

$\mathrm{p}=$ Panjang kelas

3) Membuat data frekuensi dan observasi dan membuat frekuensi ekspektasi

4) Menentukan nilai $\chi^{2}$ dari daftar

$$
\chi^{2}{ }_{h i t}=\sum \frac{(o i-e i)^{2}}{e i}
$$

5) Menentukan normalitas distribusi dengan kriteria $\chi^{2}$ hit $<\chi^{2}$ daf maka populasi berdistribusi normal.

a) Jika $\chi_{\text {hitung }}^{2}$ lebih kecil dari $\chi_{\text {tabel }}^{2} 0,95(d b)$, maka dinyatakan normal. Untuk perhitungan selanjutnya menggunakan uji kesamaan ratarata (uji $t)$

b) Jika $\chi_{\text {hitung }}^{2}$ lebih besar dari $\chi_{\text {tabel }}^{2} 0,95(d b)$, maka dinyatakan tidak normal. Untuk perhitungan selanjutnya menggunakan statistik dan non parametrik yaitu uji Wilcoxon.

b. Uji Homogenitas

1) Mencari nilai $\mathrm{F}$ dengan menggunakan rumus :

$$
\text { Fhitung }=\frac{\text { Varians lebih besar }}{\text { Varians lebih kecil }}
$$

2) Menentukan nilai F daftar dengan mencari nilai Fx (n2 - 1) (n1-1)

3) Menentukan homogenitas Variansi dengan kriteria $F$ hit $<F$ daf maka Homogenitas kedua Variansi sama.

a) Apabila Fhitung < Ftabel maka kedua variansi homogen

b) Apabila Fhitung $>$ F tabel maka kedua variansi tidak homogen.

2. Pengujian Hipotesis

Bila data berdistribusi normal dan mempunyai Variansi homogen maka pengujian hipotesis uji $t$ adalah sebagai berikut :

a. Menentukan Deviasi Standar Gabungan (DSG) 


$$
\text { Dsg }=\sqrt{\frac{(n 1-1)(v 1)^{2}+(n 2-1)(v 2)^{2}}{n 1+n 2-2}}
$$

b. Menentukan Nilai t hitung

$$
\text { thit }=\frac{X 1-\bar{X} 2}{D s g \sqrt{\frac{1}{n 1}+\frac{1}{n 2}}}
$$

c. Menentukan derajat kebebasan

$$
\mathrm{Db}=\mathrm{n} 1+\mathrm{n} 2-2
$$

d. Menentukan nilai t daftar

$$
\mathrm{T} \text { daf }(0,05)(58)=2,39
$$

e. Menentukan Hipotesis

1) Apabila $t$ hitung $<\mathrm{t}$ tabel maka Ho yang diterima artinya tidak terdapat implementasi model guided discovery learning berbasis media audiovisual terhadap peningkatan hasil belajar IPA

2) Apabila $t$ hitung $>\mathrm{t}$ tabel maka Hi yang diterima artinya terdapat implementasi model guided discovery learning berbasis media audiovisual terhadap peningkatan hasil belajar IPA.

\section{Hasil dan Pembahsan}

Data pre test hasil belajar siswa kelompok eksperimen memperoleh nilai terendah sebesar 35, nilai tertinggi sebesar 60 dan memperoleh rata-rata sebesar 50,17 berada di bawah nilai kriteria ketuntasan minimal (KKM) yang telah ditetapkan sebesar 68 , hal ini membuktikan bahwa hasil belajar siswa sebelum menerapkan model guided discovery learning berbasis media audiovisual pada konsep cahaya dan sifat-sifatnya Kelas V SD Negeri 1 Sukamulya Kabupaten Kuningan masih rendah.

Data pre test hasil belajar siswa kelompok kontrol memperoleh nilai terendah sebesar 40, nilai tertinggi sebesar 65 dan memperoleh rata-rata sebesar 51,67 berada di bawah nilai kriteria ketuntasan minimal (KKM) yang telah ditetapkan sebesar 68, hal ini membuktikan bahwa hasil belajar siswa kelompok kontrol sebelum menerapkan metode konvensional Kelas V SD Negeri 1 Sukamulya Kabupaten Kuningan masih rendah.

Hasil penelitian Ahmad (2012) membuktikan bahwa data pretest hasil belajar siswa kelas V pada mata pelajaran bahasa indonesia di SD Negeri 1 Cikijing Kabupaten Majalengka memperoleh nilai rata-rata 62,75 berada berada di bawah nilai kriteria ketuntasan minimal (KKM) yang telah ditetapkan sebesar 73.

Berdasarkan perhitungan uji statistik dengan uji normalitas data pre test hasil belajar siswa kelompok eksperimen diperoleh $\chi^{2}$ hit $(4,53)<\chi^{2}$ daf $(5,99)$ maka populasi tersebut berdistribusi normal. Begitu juga uji normalitas data pre test hasil belajar siswa kelompok kontrol diperoleh $\chi^{2}$ hit $(4,13)<\chi^{2}$ daf $(5,99)$ maka populasi tersebut berdistribusi normal. 
Berdasarkan hasil perhitungan diperoleh $\mathrm{F}$ hit $=1,13$ dan $\mathrm{F}$ daf dari hasil interpolasi F daf $(0,05)(29 / 29)=1,71$. Dengan demikian F hit $(1,13)<(1,71)$ dengan menggunakan taraf kepercayaan $(\alpha)$ 0,05 maka dapat disimpulkan bahwa nilai pre test hasil belajar siswa antara kelompok eksperimen dan kontrol mempunyai variansi yang homogen.

Data post test kelompok eksperimen memperoleh nilai terendah sebesar 65, nilai tertinggi sebesar 95 dan memperoleh rata-rata sebesar 78,17 berada di atas nilai kriteria ketuntasan minimal (KKM) yang telah ditetapkan sebesar 68, hal ini membuktikan bahwa penerapan model guided discovery learning berbasis media audiovisual dapat meningkatkan hasil belajar siswa pada konsep cahaya dan sifat-sifatnya Kelas V SD Negeri 1 Sukamulya Kabupaten Kuningan.

Data post test hasil belajar siswa kelompok kontrol memperoleh nilai terendah sebesar 60, nilai tertinggi sebesar 80 dan memperoleh rata-rata sebesar 66,83 berada di bawah nilai kriteria ketuntasan minimal (KKM) yang telah ditetapkan sebesar 68, hal ini membuktikan bahwa hasil belajar siswa kelompok kontrol setelah menerapkan metode konvensional Kelas V SD Negeri 1 Sukamulya Kabupaten Kuningan masih rendah.

Ruseffendi (2014 : 141) mengemukakan kelebihan model guided discovery learning adalah siswa belajar berfikir analisis dan mencoba memecahkan problema yang dihadapi sendiri dan biasanya akan ditransfer dalam kehidupan bermasyarakat, menimbulkan interaksi antar siswa dan melatih ketrampilan dasar yang dimiliki oleh siswa, meningkatkan penalaran, analisis dan keterampilan siswa memecahkan masalaha tanpa pertolongan orang lain, dan meningkatkan kreatifitas siswa untuk terus belajar dan tidak hanya menerima saja.

Hasil penelitian Ahmad (2012) membuktikan bahwa terdapat pengaruh media visual terhadap hasil belajar siswa kelas v pada mata pelajaran bahasa indonesia di SD Negeri 1 Cikijing Kabupaten Majalengka. Sedangkan Yuswati (2014) menunjukkan bahwa pengunaan media audiovisual dapat, meningkatkan hasil belajar siswa pada pembelajaran IPS di kelas IV PT. Lestari Tani Teladan (LTT) Kabupaten Donggala

Berdasarkan perhitungan uji statistik dengan uji normalitas data post test hasil belajar siswa kelompok eksperimen setelah dilaksanakan model guided discovery learning berbasis media audiovisual diperoleh $\chi^{2}$ hit $(5,19)<\chi^{2}$ daf $(7,81)$ maka populasi tersebut berdistribusi normal. Berdasarkan perhitungan uji statistik dengan uji normalitas data post test hasil belajar siswa kelompok kontrol dengan tetap melaksanakan pendekatan konvensional diperoleh $\chi^{2}$ hit $(4,59)<\chi^{2}$ daf $(7,81)$ maka populasi tersebut berdistribusi normal.

Berdasarkan hasil perhitungan diperoleh $\mathrm{F}$ hit $=1,59$ dan $\mathrm{F}$ daf dari hasil interpolasi F daf $(0,05)(29 / 29)=1,71$. Dengan demikian F hit $(1,59)<\mathrm{F}$ daf $(1,71)$ dengan menggunakan taraf kepercayaan $(\alpha)$ 0,05 maka dapat disimpulkan bahwa nilai post test hasil belajar siswa antara kelompok eksperimen dengan kontrol mempunyai variansi yang homogen. 
Hasil penelitian Andira menunjukkan hasil pengujian statistik thit $(8,521)>\mathrm{t}$ daf $(1,67)$, maka terima Hi artinya terdapat pengaruh model discovery learning terhadap pemahaman konsep pada siswa kelas VII SMP Negeri 1 Majalengka (Andira, 2010).

Hasil penelitian Nuryati (2012) membuktikan bahwa hasil pengujian statistik dengan uji hipotesis diperoleh $\mathrm{t}$ hit $(4,092)>\mathrm{t}$ daf $(1,67)$, maka terima Hi artinya terdapat pengaruh model guided discovery learning terhadap prestasi belajar siswa pada mata pelajaran IPA di SD Negeri 1 Cilimus Kabupaten Kuningan.

Berdasarkan perhitungan uji hipotesis dengan menggunakan uji $t$ diperoleh data $t$ hit $(5,70)>\mathrm{t}$ daf $(1,67)$, maka Hi diterima artinya bahwa terdapat pengaruh model guided discovery learning berbasis media audiovisual terhadap hasil belajar IPA pada konsep cahaya dan sifat-sifatnya di Kelas V SD Negeri 1 Sukamulya.

Berdasarkan perhitungan uji statistik dengan menggunakan uji $t$, hipotesis yang menyatakan terdapat implementasi model guided discovery learning berbasis media audiovisual terhadap peningkatan hasil belajar IPA, dapat diterima pada taraf kepercayaan $(\alpha) 0,05$.

Widdiharto (2012 : 8) mengemukakan bahwa model guided discovery learning berbasis media audiovisual dimulai kelompok belajar mendiskusikan masalah untuk dipecahkn melalui pengumpulan data, kelompok belajar merumuskan dan menetapkan jawaban sementara, siswa melakukan penemuan dengan pengumpulan dan pengolahan data, siswa dalam kelompok belajar mencatat, menganalisis penemuan dan pengamatan, kelompok belajar menyelesaikan LKS dengan memanfaatkan berbagai sumber belajar, kelompok belajar mendiskusikan konsep berdasarkan hasil penemuan, dan kelompok belajar membuat kesimpulan jawaban hasil penemuan sehingga meningkatkan hasil belajar siswa.

Hasil penelitian Handayani (2017) hasil penelitian menunjukkan model pembelajaran guide inquiry secara efektif mampu meningkatkan motivasi dan hasil belajar siswa kelas X 9 MIPA Semester 2. Hal tersebut terlihat dari meningginya motivasi belajar pada tiap tahapan siklus, dan lulusnya 93\% siswa X 9 MIPA dari kriteria ketuntasan minimum, pada akhir siklus II. Yang artinya, hal tersebut semakin menegaskan bahwa model pembelajaran ini mampu secara efektif meningkatkan motivasi belajar dan hasil belajar siswa.

Hasil penelitian Raggil menunjukkan berdasarkan hasil pengujian statistik diperoleh $\mathrm{Z}$ hit $(3,592)>\mathrm{Z}$ daf $(2,38)$, maka terima Hi artinya terdapat pengaruh model discovery learning terhadap pemahaman konsep pada siswa kelas VII SMP Negeri 1 Cilimus Kabupaten Kuningan (Raggil, 2011).

Widdiharto (2012 : 8) mengemukakan bahwa kelebihan model guided discovery learning adalah membantu siswa mengembangkan penguasaan keterampilan dari proses kognitif siswa, membangkitkan motivasi belajar siswa misalnya siswa merasakan bagaimana proses penyelidikan, menemukan keberhasilan dan kadang-kadang kegagalan, memberikan kesempatan pada siswa untuk bergerak maju sesuai dengan kemampuannya sendiri, meningkatkan kemampuan siswa untuk mengarahkan sendiri 
cara belajarnya, sehingga siswa lebih merasa terlibat, dan membantu dan memperkuat pribadi siswa dengan bertambahnya kepercayaan pada diri sendiri.

Hasil penelitian Nurcahayadi membuktikan hasil pengujian statistik Z hit $(4,173)$ $>\mathrm{Z}$ daf (2,38), maka terima $\mathrm{Hi}$ artinya terdapat pengaruh model discovery learning terhadap pemahaman konsep pada siswa kelas VII SMP Negeri 1 Kalimanggis Kabupaten Kuningan (Nurcahayadi, 2011).

Penelitian Susilowati (2012) menunjukkan bahwa hasil pengujian statistik diperoleh $\mathrm{t}$ hit $(6,027)>\mathrm{t}$ daf $(1,67)$, maka terima $\mathrm{Hi}$ artinya terdapat pengaruh media audiovisual terhadap prestasi belajar siswa pada mata pelajaran Bahasa Indonesia di kelas V SD Negeri 1 Cikijing Kabupaten Majalengka.

\section{Kesimpulan}

Kesimpulan adalah terdapat pengaruh model guided discovery learning berbasis media audiovisual terhadap hasil belajar siswa kelas V pada konsep cahaya dan sifatsifatnya di SD Negeri 1 Sukamulya. 


\section{BIBLIOGRAFI}

Ahmad, Emod. (2012). Pengaruh Media Visual Terhadap Hasil Belajar Siswa Kelas V Pada Mata Pelajaran Bahasa Indonesia di SD Negeri 1 Cikijing Kabupaten Majalengka". Jurnal PGSD FKIP UNMA. Online Vol. 2 No. 9

Andira, Indra. (2010). Pengaruh Model Discovery Learning Terhadap Pemahaman Konsep Pada Siswa Kelas VII SMP Negeri 1 Majalengka.

Dimyanti. (2014). Strategi Pembelajaran Cooperative Learning. Surabaya: Kartika.

Hadiningsih. (2016). Model Pembelajaran Kreatif. Jakarta: Bumi Aksara.

Handayani. (2017. Penerapan Metode Guided Inquiry Dalam Meningkatkan Motivasi Dan Hasil Belajar Siswa Pada Mata Pelajaran Biologi. Syntax Literate ; Jurnal

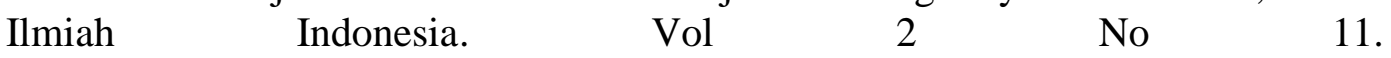
http://www.jurnal.syntaxliterate.co.id/index.php/syntax-literate/article/view/258

Iskandar, Deden. (2016). Pengaruh Yang Signifikan Penggunaan Media Audiovisual Terhadap Motivasi Belajar Dan Hasil Belajar Kelas V Pada Mata Pelajaran IPS di SD Negeri 2 Patala Kecamatan Cilebak Kabupaten Kuningan Tahun Ajaran 2015/2016. Jurnal PGSD STKIP Muhammadiyah. Online Vol. 4 No. 3

Kusumah. (2015). Media Pembelajaran. Bandung: Pustaka Setia.

Munadi, Yudhi. (2015). Media Pembelajaran Sebuah Pendekatan Baru. Jakarta: Gaung Persada Press.

Nurcahayadi, Cahya. (2011). Pengaruh Model Discovery Learning Terhadap Pemahaman Konsep Pada Siswa Kelas VII SMP Negeri 1 Kalimanggis Kabupaten.

Nuryati. (2012). Pengaruh Media Audiovisual Terhadap Prestasi Belajar Siswa Pada Mata Pelajaran IPA di SD Negeri 1 Cilimus Kabupaten Kuningan. Jurnal PGSD STKIP Muhammadiyah. Online Vol. 4 No. 3

Raggil. (2011). Pengaruh Model Discovery Learning Terhadap Pemahaman Konsep Pada Siswa Kelas VII SMP Negeri 1 Cilimus Kabupaten Kuningan.

Russefendi. 2014. Metode Pembelajaran. Bandung : PT Remaja Rosdakarya.

Sanjaya, Wina. (2019). Strategi Pembelajaran Berorientasi Standar Proses Pendidikan.

Susilawati, Masnie. (2012) Pengaruh Media Audiovisual Terhadap Prestasi Belajar Siswa Pada Mata Pelajaran Bahasa Indonesia di kelas V SD Negeri 1 Cikijing Kabupaten Majalengka. Jurnal PGSD FKIP UNMA. Online Vol. 2 No. 9

Wati, Atin Dwi Sulistia. (2012). Pengaruh Model Discovery Learning Terhadap Pemahaman Konsep Pada Siswa Kelas VII SMP Negeri 4 Cirebon. 
Pengaruh Model Guided Discovery Learning Berbasis Media Audiovisual Terhadap Hasil Belajar IPA

Widdiharto, Rachmadi. 2012. Model Pembelajaran. Yogyakarta : Pustaka Pelajar.

Yuswanti (2014). "Pengunaan Media Gambar Untuk Meningkatkan Hasil Belajar Siswa Pada Pembelajaran IPS di kelas IV PT. Lestari Tani Teladan (LTT) Kabupaten Donggala”. Jurnal Kreatif Tadulako Online Vol. 3 No. 4. 